\title{
Ammonia Volatilization from Fertilized Turfgrass Stands ${ }^{1}$
}

\author{
W. A. Torello, D. J. Wehner, and A. J. Turgeon ${ }^{2}$
}

\begin{abstract}
Nitrogen applied to turfgrass stands can be lost through leaching, denitrification, or ammonia $\left(\mathrm{NH}_{3}\right)$ volatilization. The purpose of this investigation was to evaluate the effects of $\mathrm{N}$ carrier and mode of application on $\mathrm{NH}_{3}$ volatilization from a Kentucky bluegrass (Poa pratensis L.) turf growing on an acidic (pH 6.4) Flanagan silt loam (fine, montmorillonitic, mesic Aquic Argiudoll) soil. The $\mathrm{NH}_{3}$ which volatilized after application of any of several sulfur-coated ureas (SCU), prilled urea, spray-applied solubilized urea, and two liquid $\mathbf{N}$ products was measured by passing the airstream from microecosystems, in which the treated turfs were growing, through an indicating boric acid solution to trap $\mathbf{N H}_{3}$. Ammonia-N losses after sulfur-coated urea fertilization ranged from $0.2 \%$ of the applied $\mathrm{N}$ when the fertilization rate was $98 \mathrm{~kg} \mathrm{~N}$ / ha to $2.3 \%$ of the applied $\mathrm{N}$ when the fertilization rate was $293 \mathrm{~kg} \mathrm{~N} /$ ha. When prilled urea was applied at a rate of $293 \mathrm{~kg} \mathrm{~N} / \mathrm{ha}, \mathrm{NH}_{3}$ losses averaged $10.3 \%$ of the applied $N$ whereas 4.6 and $1.6 \%$ of the applied $\mathrm{N}$ was lost after turf was fertilized with $49 \mathrm{~kg} \mathrm{~N} / \mathrm{ha}$ from spray-applied solubilized urea and prilled urea, respectively. Ammonia losses from turf treated with liquid $N$ sources ranged from 3.2 to $4.5 \%$ of the applied N. The results of this research indicate that ammonia volatilization occurs to a limited extent in turfgrass stands growing on an acidic soil.
\end{abstract}

Additional index words: Nitrogen utilization, Poa pratensis L., Urea, Sulfur-coated urea, Liquid N fertilizers.

A MMONIA $\left(\mathrm{NH}_{3}\right)$ volatilization from soils after $\mathrm{N}$ fertilization can be extensive depending on the form of $\mathrm{N}$ applied, the type of soil, and the environment at time of application. Numerous studies have been conducted to determine $\mathrm{NH}_{3}-\mathrm{N}$ loss from soils $(2,3,6,7)$. However, less information is available on $\mathrm{NH}_{3}-\mathrm{N}$ losses from turfgrass stands.

In laboratory and field experiments, Volk (7) showed that soil cation exchange capacity (CEC), temperature, and rate of soil drying were factors affecting the $\mathrm{NH}_{3}$ " $\mathrm{N}$ losses which ranged from 17 to $59 \%$ of the applied $\mathrm{N}$ after urea fertilization of bare soil. Ammonia-N losses after urea fertilization of field piots of several grasses ranged from 20 to $30 \%$ of the applied N. Volk (7) reported that losses were greater after crystalline urea applications to grass compared with prilled urea application.

Fenn and Kissel $(2,3)$, in laboratory studies, have reported $\mathrm{NH}_{3}-\mathrm{N}$ losses ranging from 16 to $68 \%$, depending on $\mathrm{N}$ source, from fertilized bermudagrass turf growing on a calcareous soil. However, when measuring $\mathrm{NH}_{3}-\mathrm{N}$ losses from field plots, Kissel et al. (4) found that only 3.9 to $6.9 \%$ of the total- $N$ applied as urea was lost through $\mathrm{NH}_{3}$ volatilization from bermudagrass also growing on a calcareous soil.

Nelson et al. (5), in laboratory studies, evaluated the extent of $\mathrm{NH}_{3}$ volatilization from turf samples growing on an acidic Flanagan silt loam soil (fine, montmorillonitic, mesic Aquic Argiudoll). These results indicated that where a thatch layer existed, up to $39 \%$ of the total-N applied as urea was lost through $\mathrm{NH}_{3}$ volatilization. Turf samples not having a thatch layer lost only $5 \%$ of the applied urea-N. These results may have overestimated actual $\mathrm{NH}_{3}-\mathrm{N}$ losses due to extremely high urea- $\mathrm{N}$ application rates of $245 \mathrm{~kg} \mathrm{~N} / \mathrm{ha}$ which is five times the normal application rate for soluble fertilizers on turfgrasses. Furthermore, the experimental systems used did not simulate leaching and, as such, all urea- $N$ applied to turf core samples was contained in a small area for the duration of the experiment. Leaching has been shown to

\footnotetext{
${ }^{1}$ Contribution from the Horticulture Dep., Univ. of Illinois at Urbana-Champaign. This study was part of project no. 65-356 of the Agric. Exp. Stn., Univ. of Illinois at Urbana-Champaign, Urbana, IL 61801. Received 10 June 1982.

${ }_{2}$ Former graduate student, Horticulture Dep., Univ. of Illinois at Urbana-Champaign (currently, assistant professor, Dep. of Plant and Soil Sci., Univ. of Massachusetts, Amherst, MA 01003); assistant professor, Horticulture Dep., Univ. of Illinois at Urbana-Champaign; Director, Texas A\&M Agric. Exp. Stn., Dallas, TX 75252.
} 
have an effect on the extent of $\mathrm{NH}_{3}$ volatilization. ${ }^{3}$

The home lawn care industry relies heavily on the use of solubilized urea and other liquid $\mathrm{N}$ sources for fertilization. In many situations, no irrigation is applied after fertilizer treatment. The potential for ammonia volatilization is increased when these materials are not washed into the soil (7). This study was undertaken for these reasons and because research results have differed in estimations of the amount of ammonia volatilized from turfgrass stands. The purpose of this research was to: 1) determine the extent of ammonia volatilization after fertilization of turf growing on an acidic Flanagan silt loam soil with urea and other urea-based fertilizers, and 2) determine the effects of mode of fertilizer application upon $\mathrm{NH}_{3}$ volatilization. Newly developed, turfgrass microecosystems were used to measure $\mathrm{NH}_{3}$ volatilization in these studies. The results from preliminary volatilization experiments using the microecosystems ${ }^{3}$ agreed well with field studies conducted by other researchers (4).

\section{MATERIALS_AND METHODS}

The turfgrass microecosystems employed in this study are described in detail by Branham. ${ }^{4}$ These systems were composed of a brass media base to hold the turfgrass sample, a glass atmospheric chamber covering the base, and a trapping system to collect volatilized ammonia. The brass media base was fitted with a ceramic plate and connected to a vacuum pump ( 400 milibar tension) so that leaching could be simulated. Air flowed through the atmospheric chamber at a rate of $4 \mathrm{~L} / \mathrm{min}$ resulting in 6.7 volume changes per hour. The airstream exiting the atmospheric chamber was passed through three boric acid traps to collect volatilized ammonia. The six microecosystems used in this research were housed in a growth chamber which provided $0.204 \mathrm{~W} \mathrm{~m}^{-2}$ light irradiance with a 12-hour daylength. The temperature inside the microecosystems was held at a constant $24 \pm 1.8 \mathrm{C}$.

The $\mathrm{NH}_{3}$ trapping efficiencies for the six turf microecosystems ranged between 95.1 and $103.0 \%$ recovery of added $\mathrm{NH}_{3}$. Standards of $\mathrm{NH}_{3}$ for efficiency tests were prepared by slowly dripping $1.0 \mathrm{~N} \mathrm{KOH}$ into a $50-\mathrm{ml}$ beaker containing a known amount of $\left(\mathrm{NH}_{4}\right)_{2} \mathrm{SO}_{4}$ within each enclosed atmospheric chamber. Ammonia librated and trapped within the boric acid traps was then quantified by titrating with $0.0462 \mathrm{~N} \mathrm{H}_{2} \mathrm{SO}_{4}$.

For all experiments, turfgrass samples were taken from a 'Kenblue' Kentucky bluegrass (Poa pratensis L.) stand growing on a Flanagan silt loam soil with a $\mathrm{pH}$ of 6.4. Total soil $\mathrm{N}$ was $0.27 \%$ and total $C$ by dry combustion was determined to be $5.9 \%$. Turf samples used in this research measured $30 \times 30 \times$ $5 \mathrm{~cm}(1 \times W \times D)$. The turf had not been fertilized during the previous 8 years. No volatilized ammonia was detected in nonfertilized controls run at the beginning of the research project. Turf samples were either taken directly from the field and placed in the microecosystems or placed in a greenhouse for future transfer to the microecosystems. Within an experiment, all samples were handled uniformly. After a 24-hour equilibration period and an application of $600 \mathrm{ml}$ distilled water to each microecosystem, an experiment was initiated by the application of fertilizer treatments. Granular fertilizers were applied by hand while liquids were sprayed on the turf with a misting bottle. Once an experiment started, subsequent irrigations and mowings $(3.5-\mathrm{cm}$ height of cut) occurred every 3 days.

The boric acid traps (1.5 N boric acid) were checked daily for changes in color during an experiment. A titratable change in color resulted when $0.2 \mathrm{mg}$ or more of $\mathrm{N}$ was collected from

\footnotetext{
${ }^{3}$ Torello, W.A. 1981. Ammonia volatilization and urease activity in turf, Ph.D. Thesis. Univ, of Illinois, Urbana.

4 Branham, B.E. 1980. Development of a 'microecosystem for determining the fate of pesticides in turf. M.S. Thesis. Univ. of lllinois, Urbana.
}

a microecosystem. An experiment was terminated when the interval between titrations exceeded 2 days. Four separate experiments were conducted. Data from each experiment were subjected to an analysis of variance and LSD values calculated where appropriate.

\section{Experiment No. 1}

In this experiment sulfur-coated urea supplied by Lakeshore Equipment Co. (36-0-0, 28\% dissolution rate, manufactured under license by the Tennessee Valley Authority) was compared to sulfur-coated urea supplied by Canadian Industries Limited (32-0-0,30\% dissolution rate) and prilled urea for loss of $\mathrm{NH}_{3}$ through volatilization. All treatments were applied at the rate of $293 \mathrm{~kg} \mathrm{~N} / \mathrm{ha}$. Each treatment was replicated twice. This experiment lasted 21 days.

\section{Experiment No. 2}

The amount of $\mathrm{NH}_{3}$ volatilized from turf fertilized with sulfur-coated urea materials manufactured by the Tennessee Valley Authority with 7-day dissolution rates of $18,27.3$, and $37.5 \%$ was determined. Each treatment was applied at the rate of 98 $\mathrm{kg} \mathrm{N} / \mathrm{ha}$ and replicated two times. The experiment lasted 14 days.

\section{Experiment No. 3}

The amount of ammonia volatilized from turf samples fertilized with either prilled urea or spray-applied solubilized urea was determined. The rate of fertilizer application was $49 \mathrm{~kg} \mathrm{~N} /$ ha. Spray treatments were applied in a volume of $1629 \mathrm{~L} / \mathrm{ha}$. Three replications were utilized in this experiment which lasted 10 days.

\section{Experiment No. 4}

Two popular liquid $\mathbf{N}$ sources that are used in the lawn care industry were applied to turf samples and the volatilized ammonia was collected and quantified. One source was a low molecular weight, water soluble, ureaformaldehyde reaction product containing approximately $50 \%$ free urea with the remainder being methylol and soluble methylene urea (analysis 30-0-2, trade name Formolene, Hawkeye Chemical Co.). The other liquid source was a suspension fertilizer product consisting of low molecular weight, water-soluble, and water-insoluble ureaformaldehyde reaction products in which $35 \%$ of the $N$ is free urea (analysis 17 $0-0$, trade name Fluf, W.A. Cleary Chemical Co.). The first product will be referred to as methylol urea while the second product will be referred to as suspension UF. Both materials were applied at the rate of $49 \mathrm{~kg} / \mathrm{ha}$ of $\mathrm{N}$ to three replicate turf samples.

\section{RESULTS AND DISCUSSION}

\section{Experiments No. 1 and 2: Sulfur-Coated Urea}

There were negligible losses of ammonia from turf samples that had been fertilized with any of the S-coated urea (SCU)-N sources (Table 1). Even when applied at a rate $(293 \mathrm{~kg} / \mathrm{ha}$, Exp. No. 1) three times that which is normally used for sulfur-coated urea on commercial areas, only 1.1 to $2.3 \%$ of the $\mathrm{N}$ was lost as ammonia compared with a $10.3 \%$ loss from urea-fertilized turf. Experiment No. 1 was terminated after 21 days because only small amounts of $\mathrm{NH}_{3}$ were being collected in the boric acid traps. After the 10th day of the experiment, the traps were sampled every 3 days. However, slight color changes occurred up to the 21 st day indicating that long-term studies might reveal more extensive $\mathrm{NH}_{3}-\mathrm{N}$ losses from sulfur-coated urea-fertilized turf.

In Exp. No. 2, the sulfur-coated urea having the highest dissolution rate exhibited a significant increase in $\mathrm{NH}_{3}$ 
Table 1. Comparison of $\mathrm{NH}_{3}$ volatilized from turf samples after applications of urea and various S.coated urea materials. Numbers in parentheses indicate dissolution rates.

\begin{tabular}{lcccc}
\hline Treatment & $\begin{array}{c}\text { Rate of } \mathrm{N} \\
\text { application }\end{array}$ & $\begin{array}{c}\text { Duration of } \\
\text { experiment }\end{array}$ & $\begin{array}{c}\text { Total N } \\
\text { volatilized }\end{array}$ & $\begin{array}{c}\text { Applied N } \\
\text { volatilized }\end{array}$ \\
\hline & $\mathrm{kg} \mathrm{N} / \mathrm{ha}$ & days & $\mathrm{mg}$ & $\%$ \\
Urea & 293 & 21 & 281.0 & 10.3 \\
CIL-SCU & 293 & 21 & 30.7 & 2.3 \\
LESCO-SCU & 293 & 21 & 61.5 & 1.1 \\
LSD (0.05) & & & & 3.45 \\
TVA-SCU & 98 & 14 & 6.2 & 0.7 \\
(37.5) & 98 & 14 & 1.9 & 0.2 \\
(27.2) & 98 & 14 & 1.7 & 0.2 \\
(18.0) & & & & 0.1 \\
LSD (0.01) & & & & \\
\hline
\end{tabular}

$\uparrow$ Data represent the mean $(\bar{x})$ of two replications.

volatilization over the materials having lower dissolution rates (Table 1, Exp. No. 2). The overall magnitude of $\mathrm{NH}_{3}-\mathrm{N}$ loss was much less in Exp. No. 2 where the normal commercial application rate of $98 \mathrm{~kg} \mathrm{~N} /$ ha was used. A $\mathrm{N}$ application rate-volatilization interaction has been reported (7).

The low levels of $\mathrm{NH}_{3}-\mathrm{N}$ losses associated with all $\mathrm{SCU}$ materials tested is most likely due to the $\mathrm{S}$ coating and sealant compounds which overlay the $S$ coating. The sealant compounds not only limit the dissolution of urea from the granule, but also have an inhibitory effect upon microbial activity (1).

\section{Experiment No. 3: Mode of Urea Application}

Almost three times as much $\mathrm{N}$ was lost through ammonia volatilization from turf treated with spray-applied solubilized urea vs. prilled urea (Table 2) at a rate of 49 $\mathrm{kg} / \mathrm{ha}$. The increased level of volatilization from turf treated with spray-applied solubilized urea can be explained by considering results reported by Volk (7), the volume of water used to apply the treatment, the amount of urease activity on the surface of turfgrass plants, and the $\mathrm{pH}$ change brought about by the hydrolysis of urea, Volk (7) measured more $\mathrm{NH}_{3}$ volatilization after crystalline urea applications to turf than with pelleted urea applications. He stated that the higher losses after crystalline urea application probably resulted from a greater tendency for the crystals to cling to the grass rather than penetrate to the surface humus where the possibility of efficient cation absorption was greater. The amount of water used to apply the urea spray in this research was not great enough to move the urea solution into the soil but, rather, coated the plants with a urea film. Urease activity is extremely high on the surface of turfgrass plants ${ }^{3}$ and thus, the urea would be hydrolyzed very rapidly. The hydrolyzing urea would change the $\mathrm{pH}$ of the water film coating the turfgrass and thus promote am* monia volatilization. This explanation implies that ammonia volatilization could occur from turf, growing on any type of soil, treated with spray-applied solubilized urea unless the sprays are washed into the soil with additional water.

The urea application rate used in Exp. No. 3 was onesixth the application rate of urea used in Exp. No. 1 (49 $\mathrm{kg} / \mathrm{ha}$ vs. $293 \mathrm{~kg} / \mathrm{ha}$ ). The amount of ammonia volatilized, although not compared directly in the same experiment, was $1.7 \%$ for the low rate vs. $10.3 \%$ for the high rate. Other researchers (4) have reported rate effects on ammonia volatilization. The standard application rate of
Table 2. Ammonia volatilized from turf after treatment with either prilled urea or spray-applied solubilized urea. Nitrogen application rate for all treatments was $453.6 \mathrm{mg}$ N/turf slab which is equivalent to $49 \mathrm{~kg} \mathrm{~N} / \mathrm{ha}$,

\begin{tabular}{|c|c|c|c|}
\hline Treatment & $\begin{array}{l}\text { Duration of } \\
\text { experiment }\end{array}$ & $\begin{array}{c}\text { Total N } \\
\text { volatilized } \dagger\end{array}$ & $\begin{array}{l}\text { Applied N } \\
\text { volatilized }\end{array}$ \\
\hline & days & $\mathrm{mg}$ & $\%$ \\
\hline $\begin{array}{l}\text { Prilled } \\
\text { Spray-applied urea }\end{array}$ & $\begin{array}{l}10 \\
10\end{array}$ & $\begin{array}{r}7.4 \\
20.9\end{array}$ & $\begin{array}{l}1.6 \\
4.6^{* *}\end{array}$ \\
\hline
\end{tabular}

Table 3. Comparison of $\mathrm{NH}_{3}$ volatilized from turf slabs treated with methylol urea or suspension UF. Both fertilizers were applied at $49 \mathrm{~kg} \mathrm{~N} / \mathrm{ha}$.

\begin{tabular}{lccc}
\hline Treatment & $\begin{array}{c}\text { Duration of } \\
\text { experiment }\end{array}$ & $\begin{array}{c}\text { Total N } \\
\text { volatilized } \dagger\end{array}$ & $\begin{array}{c}\text { Applied N } \\
\text { volatilized }\end{array}$ \\
\hline & days & $\mathrm{mg}$ & $\%$ \\
Suspension UF & 4 & 14.5 & 3.2 \\
Methylol urea & $\mathbf{4}$ & 20.3 & $4.5^{* *}$ \\
\hline
\end{tabular}

** Significant $F$ value $(P=0.01)$.

†Data represent the mean $(\overline{\mathbf{x}})$ of three replications.

urea on commercial turf is approximately $49 \mathrm{~kg} / \mathrm{ha}$.

\section{Experiment No. 4: Liquid N Materials}

The extent of $\mathrm{NH}_{3}$ volatilized from turf treated with the liquid $\mathrm{N}$ materials is presented in Table 3. Ammonia losses from both materials were two to three times greater than previously measured $\mathrm{NH}_{3}-\mathrm{N}$ losses after prilled urea applications (Table 2) but similar in magnitude to losses after liquid urea applications. There was less ammonia lost from turf treated with the suspension ureaformaldehyde product than the methylol urea product. Both of these liquid $\mathrm{N}$ materials contain a mixture of short-chained ureaformaldehyde units and free urea (35 to $50 \%$ of the total- $\mathrm{N}$ as free urea). Since $\mathrm{NH}_{3}$ volatilization after application of these materials was comparable to that observed after liquid urea applications at the same $\mathrm{N}$ application rate, it was thought that in addition to urease, other enzymes for ureaformaldehyde hydrolyzation may be produced on turfgrass tissue or surface organic matter above the soil. Further work indicated that neither urease or any other enzyme located upon turfgrass tissue could efficiently hydrolyze short-chained ureaformaldehydes. ${ }^{3}$ Therefore, it was assumed that the urea content of each material was responsible for the observed $\mathrm{NH}_{3}-\mathrm{N}$ losses.

\section{LITERATURE CITED}

1. Beaton, J.D., and R.L. Fox, 1971, Production, marketing, and use of sulfur products. p. 335-379. In R.A. Olson (ed.) Fertilizer technology and use. Soil Sci. Soc. of Am., Madison, Wis.

2. Fenn, L,B, and D.E. Kissel. 1973. Ammonia volatilization from surface applications of ammonium compounds on calcareous soils I. General theory. Soil Sci. Soc. of Am. Proc, 37:855-859.

3. - and $\longrightarrow$. 1974. Ammonia volatilization from surface applications of ammonium compounds on calcareous soils. II. Effects of temperature and rate of ammonium nitrogen application. Soil Sci. Soc, of Am. Proc. 38:206-210.

4. Kissel, D,E, H.S. Brewer, and G.F. Arkin. 1977. Design and test of a field sampler for ammonia volatilization. Soil Sci. Soc. of Am. J. $41: 1133-1138$

5. Nelson, K.E., A.J. Turgeon, and J.R. Street. 1980. Thatch influence on mobility and transformation of nitrogen carriers applied to turf, Agron. J. 72:487-492

6. Russell, E.W. 1973. Soil conditions and plant growth. 10th ed. Long. man Group Limited, London.

7. Volk, G.M. 1959, Volatile loss of ammonia following surface ap. plication of urea to turf or bare soils, Agron. J, 51:746-749. 